\title{
MTT Assay of Cissus Quadrangularison Hela Cell Line
}

\author{
S.Geetha, R.Vasuki
}

\begin{abstract}
Approval of the helpful restorative properties of different indigenous plants has increased monstrous significance as they can be utilized as an elective wellspring of lead mixes in pharmacological ventures to handle numerous advanced issues, for example, tranquilize obstruction in microorganisms and nonparticularity in chemotherapeutic operators. Cissusquadrangularis Linn.is one such plant which has been generally utilized for therapeutic purposes in customary frameworks of prescription. Thus this work looks to approve the anticancer property of methanolic and ethanolic concentrates of the plant against HeLa cell line. The IC50 fixation was recorded at $62.5 \mathrm{ug} / \mathrm{ml}$ for methanolic separate and $125 \mathrm{ug} / \mathrm{ml}$ for ethanolic remove. The outcomes unmistakably uncovered that the methanolic concentrate of Cissusquadrangularis was progressively powerful on HeLa cell line when contrasted with ethanolic extricate.
\end{abstract}

Keywords: HeLa Cell line, Ethanol Extract, Methanol Extract.

\section{INTRODUCTION}

One of the significant medical problems which plague the created and creating nations alike is malignant growth. As indicated by measurements, there are 2.5 million individuals influenced by malignancy of which 8,00,000are new malignant growth cases and this infection is known to be the reason for the demise of 5,50,000 individuals every year (Sheik et al, 2015). Modalities of treatment to handle malignant growth incorporate chemotheraphy, radiation and medical procedure, which are given as individual treatment or in blend. Because of the different disadvantages related with these medicines, a quest for substitute, safe and cost proficient strategy proceeds.

Plants are incredible wellspring of different bioactive mixes which make them possibility for the different medication Research. Numerous restorative plants have been utilized in different customary therapeutic practices from days of yore. Plant subsidiaries and auxiliary metabolites are advanced with various natural properties assume an indispensable job in restoring various deadly maladies (subramaniyamDeepika and Immanuel Selvaraj, 2016).Hence the logical examination on the extraction of dynamic particles and the assessment of its anticancer potential is the need of great importance.

Cissusquadrangularis Linn.is one such plant which has been generally utilized for medicinal reason. It is a desert plant like jointed climber having a place with the family Vitaceae. It is called Pirandai in Tamil. This lasting plant is local to India or Sri Lanka, Its stem is quadrangular fit as a fiddle having four winged internodes choked at hubs (The Ayurvedic pharmacopeia of India). The different bioactive mixes like flavanoids and indanes, polysterol and kerosteroid in Cissusquadrangularis Linn, made this as one of the significant restorative plantsand these bioactive mixes have been utilized in heaps ,bone crack ,torment in joints, swelling, scurvy, gout and furthermore goes about as an antioxidant,antimicrobial , hostile to - provocative and anticancer mixes (Sadhana et al ., 2018). Since this plant with novel bioactive mixes has been demonstrated to show promising restorative and pharmacological applications, the present examination was attempted to discover the capability of Cissusquadrangularis Linn on the survival of cervical disease cell line - HeLa.

\section{MATERIALS AND METHODS}

Cissusquadrangularis Linn. plant was gathered from the greenhouse and the plant was validated by Prof P.Jayaramen, Plant Anatomy Research Centre,Chennai.The tests were shade dried and powdered.Twenty five gram of powdered example was extricated with $250 \mathrm{ml}$ of methanol and ethanol independently utilizing soxhlet mechanical assembly for $10 \mathrm{hrs}$. The concentrate was concentrated utilizing turning evaporator under decreased weight at 50 C.The buildup was made to a convergence of $100 \mathrm{mg} / \mathrm{ml}$ and put away in cooler for further use (Parang et al.,2013).

\section{In vitro anticancer Activity}

HeLacell line was gotten from National community for cell sciences Pune (NCCS). The cells were kept up in DMEM with $10 \%$ FBS, penicillin $(100 \mathrm{U} / \mathrm{ml})$, and streptomycin $(100 \mu \mathrm{g} / \mathrm{ml})$ in a humidified environment of 50 $\mu \mathrm{g} / \mathrm{ml} \mathrm{CO} 2$ at $37^{\circ} \mathrm{C}$.

In-vitro test of anticancer action of the methanol and ethanol concentrate of the stem of Cissusquadrangularis Linn. were contemplated against HeLa cell line utilizing MTT Assay. Cells $(1 \times 105 /$ well $)$ were seeded in 24 -well plates and brooded in $370 \mathrm{C}$ with $5 \% \mathrm{CO} 2$ condition. In the wake of accomplishing intersection, the cells were treated with different centralizations of the examples and further hatched for $24 \mathrm{hrs}$. On fruition every one of the wells were washed with DMEM without serum. $100 \mu 1 /$ well $(5 \mathrm{mg} / \mathrm{ml})$ of $0.5 \% \quad 3-(4, \quad 5$-dimethyl-2-thiazolyl)- 2,5-diphenyltetrazolium bromide (MTT) was included and brooded for 4 hours. After hatching, $1 \mathrm{ml}$ of DMSO was included all the wells. The absorbance at $570 \mathrm{~nm}$ was estimated with UVSpectrophotometer utilizing DMSO as the clear ( Mosmann, 1983). The \% cell suitability was determined utilizing the accompanying recipe: Biher

Dr.R.Vasuki, Department of Biomedical Engineering.Biher 
$\%$ Cell viability $=$ A570 of treated cells $/$ A570 of control cells $\times 100$

Results :

The consequence of the MTT Assay demonstrating the \% cell feasibility for the methanol and ethanol concentrates of the stem of Cissusquadrangularis on Hela cell line is appeared in Tableland 2.The most minimal cell suitability of $21.64 \%$ and $30.48 \%$ was acquired at a centralization of $1000 \mu \mathrm{g} / \mathrm{ml}$ of methanol and ethanol remove individually, while it was most elevated at $73.65 \%$ and $74.45 \%$ at $7.8 \mu \mathrm{g} / \mathrm{ml}$ of methanol and ethanol extricate separately.

The IC50 esteem which is the grouping of the example at which half of the malignant growth cells are feasible was observed to be at the convergence of $65 \mu \mathrm{g} / \mathrm{ml}$ for methanol separate and $125 \mu \mathrm{g} / \mathrm{ml}$ for ethanol extract individually

MTT assay of methanol extract of Cissusquadrangularis extract onHeLa cell line

\begin{tabular}{|c|c|c|c|c|}
\hline $\begin{array}{c}\text { S. } \\
\text { No }\end{array}$ & $\begin{array}{l}\text { Concentration } \\
(\mu \mathrm{g} / \mathrm{ml})\end{array}$ & Dilutions & $\begin{array}{c}\text { Absorbance } \\
(\text { O.D })\end{array}$ & $\begin{array}{c}\text { CellViability } \\
(\%)\end{array}$ \\
\hline 1 & 1000 & Neat & $\mathbf{0 . 3 5 0}$ & 21.64 \\
\hline 2 & 500 & $1: 1$ & 0.435 & 26.90 \\
\hline 3 & 250 & $1: 2$ & 0.544 & 33.64 \\
\hline 4 & 125 & $1: 4$ & 0.664 & 41.06 \\
\hline 5 & 62.5 & $1: 8$ & 0.783 & 48.42 \\
\hline 6 & 31.2 & $1: 16$ & 0.912 & 56.40 \\
\hline 7 & 15.6 & $1: 32$ & 1.053 & 65.12 \\
\hline 8 & 7.8 & $1: 64$ & 1.191 & 73.65 \\
\hline 9 & Cell control & - & 1.617 & 100 \\
\hline
\end{tabular}

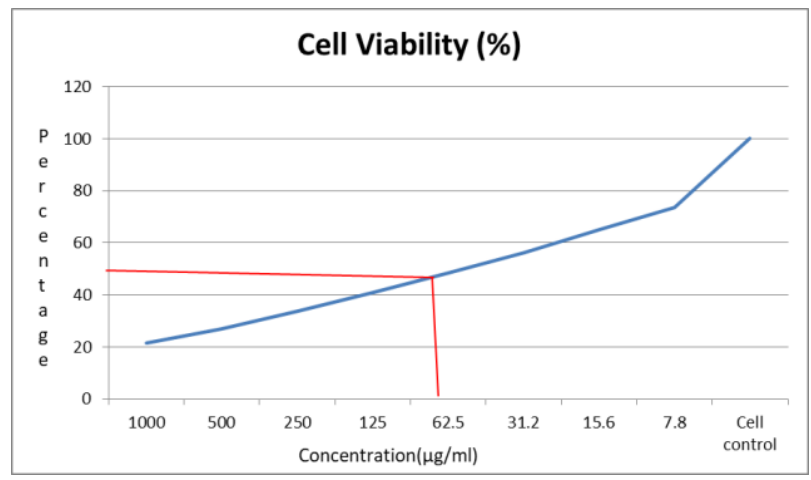

Anticancer effect of ethanol extract of Cissusquadrangularis on HeLa Cellline

\begin{tabular}{|c|c|c|c|c|}
\hline $\begin{array}{c}\text { S. } \\
\text { No }\end{array}$ & $\begin{array}{c}\text { Concentration } \\
(\mu \mathrm{g} / \mathrm{ml})\end{array}$ & Dilutions & $\begin{array}{c}\text { Absorbance } \\
(\text { O.D })\end{array}$ & $\begin{array}{c}\text { Cell Viability } \\
(\%)\end{array}$ \\
\hline 1 & 1000 & Neat & $\mathbf{0 . 4 9 3}$ & 30.48 \\
\hline 2 & 500 & $1: 1$ & 0.584 & 36.11 \\
\hline 3 & 250 & $1: 2$ & 0.672 & 41.55 \\
\hline 4 & 125 & $1: 4$ & 0.788 & 48.73 \\
\hline 5 & 62.5 & $1: 8$ & 0.879 & 54.35 \\
\hline 6 & 31.2 & $1: 16$ & 0.989 & 61.16 \\
\hline 7 & 15.6 & $1: 32$ & 1.115 & 68.95 \\
\hline 8 & 7.8 & $1: 64$ & 1.204 & 74.45 \\
\hline 9 & Cell control & - & 1.617 & 100 \\
\hline
\end{tabular}

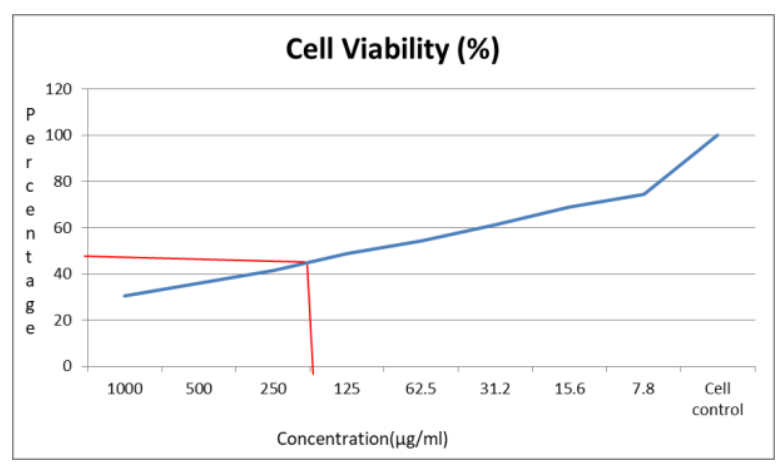

Anticancer effect of methanol extract of Cissusquadrangularis extract on HeLaCellline

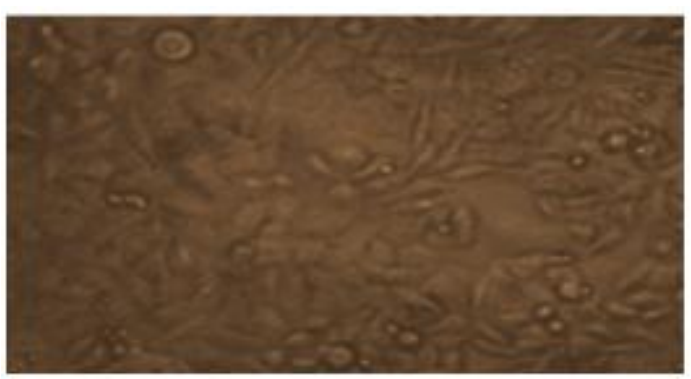

Normal HeLa Cell line

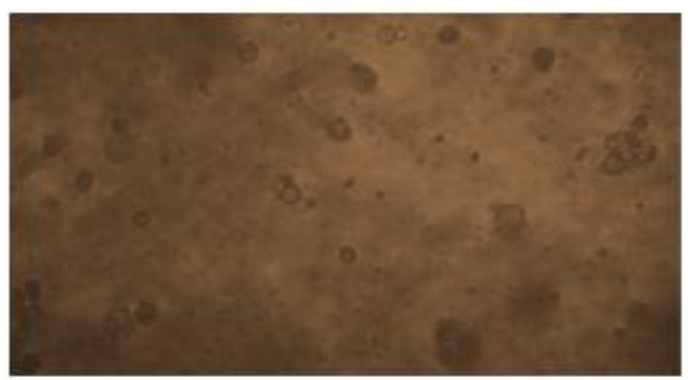

Toxicity- 1000 $\mu \mathrm{g} / \mathrm{ml}$

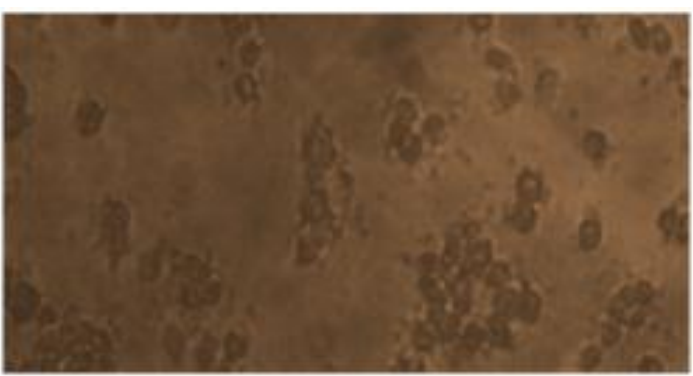

Toxicity- $62.5 \mu \mathrm{g} / \mathrm{ml}$

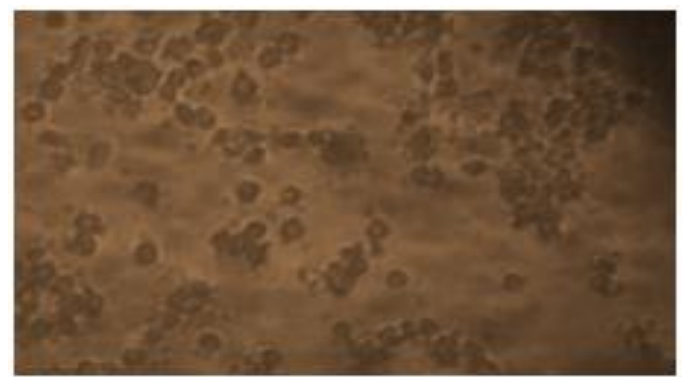

Toxicity- $7.8 \mu \mathrm{g} / \mathrm{ml}$

Published By: 


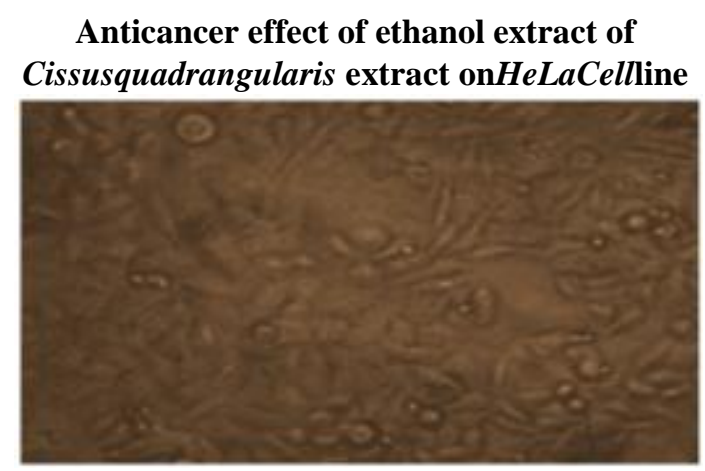

Normal HeLa Cell line

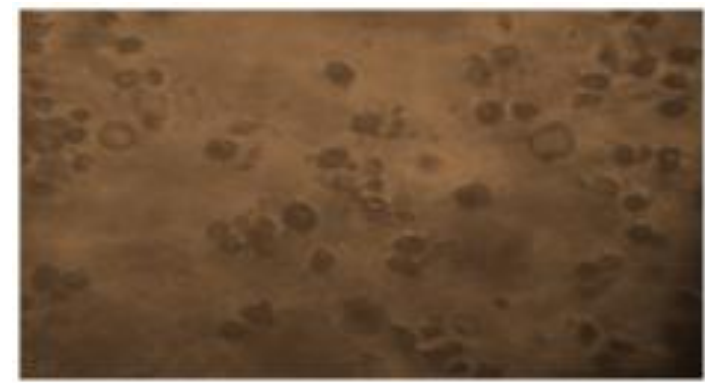

Toxicity- $1000 \mu \mathrm{g} / \mathrm{ml}$

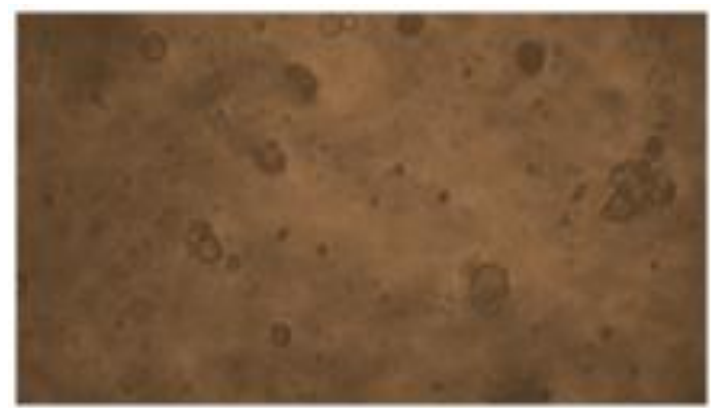

Toxicity- $125 \mu \mathrm{g} / \mathrm{ml}$

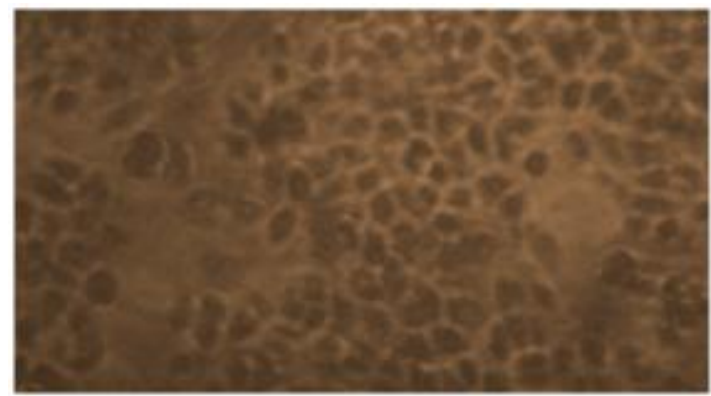

Toxicity- 7.8ug/ml

\section{DISCUSSION RESULTS}

CissusquadrangularisLinn.has been shown to possess medicinal properties to cure a number of diseases .Various studies on the cytotoxic activity of Cissusquadrangularison of oral cancer, breast cancer, cervical cancerand siddha drug formulation consisting of Cissusquadrangularishas been used to treat various forms of cancer(Rajamaheswari,2017).

The present study evaluates the cytotoxicity of methanol and ethanol extracts of Cissusquadrangularison the Hela cell lines. The methanol extracts showed an IC50 value at various cell line has shown it to be useful for management

$62.5 \mu \mathrm{g} / \mathrm{ml}$ concentration while the ethanol extracts showed an IC50 value at $125 \mu \mathrm{g} / \mathrm{ml}$ concentration. Similar results has been carried out by AayushDwivediet al.,(2013)who reported that the methanol and ethanol extracts of Cissusquadrangularis was found to exhibiting anticancer activity in HeLa and Vero cell lines with IC50 values of $62.5 \mu \mathrm{g} / \mathrm{ml}$ and $125 \mu \mathrm{g} / \mathrm{ml}$ respectively. Vijayalakshmiet al., (2013) had stated that flavonoid fractions and ethanol extracts had shown anticancer activity in MCF7 cell line with the IC50 values of $10 \mu \mathrm{g} / \mathrm{mL}$ and $40 \mu \mathrm{g} / \mathrm{mL}$ respectively.

Sheikh et al (2015) reported that Cissusquadrangularis suppress the growth of HeLa cells without damaging the normal cells at the concentration of $200 \mathrm{ug} / \mathrm{ml}$ (IC50 ).It triggers the ROS liberation in cancer cells which mediates the apoptosis and G1 phase cell cycle arrest.

Anticancer activity oftheethanolic extract of Cissusquadrangularis was observed in KB oral epidermoid carcinoma cells that resulted inchanges in cell morphology likecell shrinkage, plasma membrane blebbing, loss of cell membrane asymmetry(Sheikh et al., 2015).NaganiKrunal and ChandaSumitra(2013) had shown that chloroform and ethanol extract of Cissusquadrangularis exhibited cytotoxicity of $80.60 \%$ and $85.40 \%$ at $1000 \mu$ on Ehrlich Ascites Carcinoma cell line. Extract of Cissusquadrangularis in combination with the extract of Aeglemarmalosshowed cytotoxic activity against colon cancer HT29 cell lines.

\section{CONCLUSION}

In the present study, the methanol extracts showed an IC50 at $62.5 \mu \mathrm{g} / \mathrm{ml}$ concentration while the ethanol extracts showed an IC50 value at $125 \mu \mathrm{g} / \mathrm{ml}$ concentration. From these results it may be concluded that methanolic extract of Cissusquadrangularishas a more potent cytotoxic effect on the HeLa cell lines when compared to the ethanolic extract. Future studies may throw further light on the anti cancerous activity of Cissusquadrangularis.

\section{REFERENCES}

1. AayushDwivedi, I. Seethalakshmi and D. Sharmila, Anticancer properties of Cissusquandrangularis, Journal of Chemical and Pharmaceutical Research, 2013, 5(5):135-139.

2. NaganiKrunaland Chanda Sumitra,2013. Antioxidant and Anticancer Activity of Cissusquadrangularis L. Stem, LAP Lambert Academic Publishing, 76 Pages.

3. Parang.A and BR. Pednekar.2013.Assessment of Semecarpusanacardium(linn.f)leaf methanolic extract for their anti-bacterial,anti-fungal and anti-oxidant activity. IntJ.Pharm Sci.5:1.

4. Rajamaheswari,K, S.Visweswaran, N.J.Muthukumar, M.Murugesan, V.Banumathi.2017.Int. J. Curr. Res. Chem. Pharm. Sci. 4(8): 1-3.

5. Saba Sheikh, Sahabjadasiddiqui, Anupamdhasmana, Safia, EjazulHaque, Mohammed kamil, Mohrashimlohani, Mohammadarshad, Snobershabham Mir.2015. Cissusquadrangularis Linn. Stem Ethanolic Extract Liberates Reactive Oxygen Species and Induces Mitochondria Mediated Apoptosis in KB Cells. PharmacognMaq . Oct; 11(Suppl 3): S365-S374.

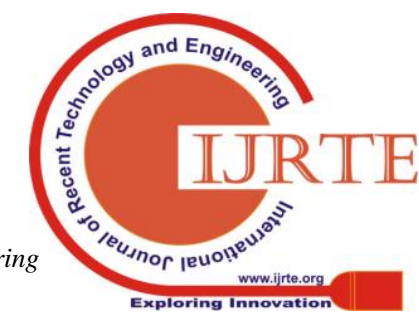


6. Saba Sheikh,AnupamDhasmana,SahabjadaSiddiqui, Safia, Ejazulhaque,Mohd, Kamil, MohtashimLohani, Mohd.Arshad, Snober S.Mir.2015.Anticancer activity of CissusQuadrangularis: An in vitro 2D model based study.International journal of sciences.Volume 23, No1. Pp: 93-105.

7. Sadhana,B.K,Gopinath,L.R,Archaya,S,Rajamuni,P,andB.T.Su resh Kumar .2018.Qualitative and quantitative analysis of CissusQuadrangularis using different extracts. Journal of Pharmacy and biological Sciences.Vol.13,Issue III.PP:57-60.

8. SubramaniyamDeepika and C.Immanuel Selvaraj.2016. Anticancer mechanism of unexplored plant compounds - A review.Journal of Biotechnology.Vol.11 .(11).

9. The Ayurvedic Pharmacopoeia Of India, Part 1, Vol III, Page no. 22.

10. The Wealth of India. A dictionary of Indian raw materials and industrial products, 1992, Raw Materials, Vol. 3: Ca-Ci, Publications \& Information Directorate, Council of Scientific and Industrial Research (CSIR), K.S.KrishnanMarg, New Delhi. Page no. 593.

11. Tim Mosmann.Rapid Colorimetric assay for cellular growth and survival: Application to proliferation and cytotoxicity assays.Journal of Immunological methods.65(1-2) 1983.5563.

12. Vijayalakshmi,A, P.R.Kumar, S.SakthiPriyadarsini, C.Meenakshi.2013.

13. In Vitro Antioxidant and Anticancer Activity of Flavonoid Fraction from the Aerial Parts of Cissusquadrangularis Linn. against Human Breast Carcinoma Cell Lines. Journal of Chemistry, Volume 2013 (2013), Article ID 150675, 9 pages. 